Research Article

\title{
Transnational family support and perspectives from family members back home: a pilot study in Kisumu, Kenya
}

\author{
Lisa Merry', Dominic Mogere ${ }^{2}$, Dan Odindo ${ }^{3}$, Nancy Edwards ${ }^{4}$ \\ ${ }^{1}$ Faculty of Nursing, University of Montreal, Montreal, Canada, ${ }^{2}$ School of Public Health, Mount Kenya University, Thika, Kenya, ${ }^{3}$ Department of \\ Community Health and Development, Great Lakes University of Kisumu, Kisumu, Kenya, ${ }^{4}$ School of Nursing, University of Ottawa, Ottawa, Canada \\ Keywords: global health
}

https://doi.org/10.29392/joghr.3.e2019025

Journal of Global Health Reports

Vol. 3, 2019

\section{Background}

Transnational family support as a resource for migrants is understudied, particularly from the perspective of those providing support from a distance. This pilot study aimed to determine the feasibility of conducting transnational research and gathering data from family members back home using communication technology. Preliminary data on the experience of providing transnational support to migrant family members living abroad, were also collected.

\section{Methods}

We conducted a small, qualitative descriptive study in Kisumu, Kenya. A convenience, purposive sample of six men and three women, who self-identified as providing support to migrant family members living in another country were recruited. Data were collected via semi-structured interviews through Skype phone calls with a researcher in Canada.

\section{Results}

Participants had various relationships (sibling, spouse, parent, uncle, cousin) to those who migrated; family members lived in the UK, US and Canada. Gathering data virtually was feasible, although there were some practical challenges and communication barriers. Interviews revealed that participants were open to share and highlighted the importance of obtaining perspectives from different family members and asking a variety of questions to elicit both positive and negative experiences. The risk of sensitive topics causing distress, raises some ethical concerns about how researchers may adequately respond and provide support from a distance. The preliminary data collected on the experiences of providing transnational family support showed that participants provided financial, emotional, spiritual and practical support. Support varied with time, with help being more intense during early resettlement and in times of financial difficulty; gender, relationship and closeness seemed to shape the nature and extent of support given. Participants mostly felt positive about their family members' migration although they also disclosed experiences of conflict and tension, which were in part due to the support-giving context.

\section{Conclusions}

Family members back home are willing to engage in transnational research and using communication technology is an efficient and logistically feasible approach for gathering data from these participants. Including family members' back home in research yields informative data on transnational family support.

It is widely recognized that migrants maintain connections to their home countries, including social, economic, cultural, political, and familial ties. ${ }^{1}$ It is also known that these transnational connections have impacts, both positive and negative, for the migrants and the families and societies in the sending countries. ${ }^{1}$ One area of research that has received significant attention in this field is transnational family support, defined as the exchange of goods, money and information, and social and emotional interactions, between families across borders. ${ }^{2-4}$ This research, however, has primarily focused on support giving by migrants towards their home country, including distancemothering, caring for elderly across borders and sending remittances. ${ }^{4-6}$ There has been less emphasis in the literature on transnational family support for migrants, espe- 
cially from the perspective of the family members in the home country who are providing the transnational support.

The limited research that exists on transnational family support for migrants suggests that support received from family back home tends to primarily be in the form of psychological and social support, which may contribute to a sense of belonging, connection and well-being for migrants. ${ }^{3,7-10}$ These studies have mainly focused on the perspectives of the migrants and those that include family back home were living in European or more developed countries. Perspectives have also mostly been limited to those of grandparents. Other research in the field, has focused on grandparents and other family kin, mostly women, who provide support by caring for children who remain behind and/or by making extended visits to the migrant families and caring for children in the host country. ${ }^{3,11}$ Findings from this body of research, show that for family members providing the support, they may feel honored and satisfaction in helping their migrant family members, however they may also experience stress, and/or feel support is not adequately reciprocated. ${ }^{9}$ For migrant parents, they may experience difficulty negotiating their parenting role in a context where children are mainly being raised by family caregivers in the home country. ${ }^{9}$ The detailed experiences of what it is like for family members in the home country to provide other types of support from a distance, and their perspectives on how they feel they are contributing to their migrant family members' life in the new country, the emotions that they experience, and the impact on their lives and relationships with family (both locally and abroad), however, remains relatively unexplored. To better understand transnational family dynamics and the support networks maintained across borders, more in depth documentation is needed on the support giving provided to migrants by their family members in the home country, especially in different migration contexts (eg, forced versus non-forced migration; migration from low- and middle-income countries as well as high-income countries). Moreover, to fully capture the transnational dynamic and to comprehend the impact on the lives of migrants as well as those back home, studies on transnational family support should include the perspectives of different family members, both in the home and migration countries. ${ }^{1,12,13}$

To begin to address the gap on transnational family support for migrants, a study is being planned. The objective of this study will be to gather data from a diverse group of migrant families living in Montreal, Canada and also from their family members back home, who are living in various countries around the world. Cross-country research traditionally consists of travelling across sites and gathering data in person. ${ }^{14-17}$ However, given the planned study intends to include migrants from a multitude of source countries, interviews with family members back home will only be feasible if conducted through phone or internet (video) calls. Given limited research in this area and the proposed distance interviewing for data collection with those living abroad, the current study therefore aimed to determine the feasibility of conducting transnational research, particularly in the context of a low-income country, via the use of communication technology. Specifically, the current pilot study aimed to address the following questions: 1) Are fam- ily members in the home country interested and willing to engage in this type of research? 2) Is it feasible to gather data using communication technology, including observational data? and 3) Who (which family members) should be included and what questions should be explored? We also used this opportunity to gather some preliminary data on the experience of providing transnational family support from the perspective of family members back home.

\section{METHODS}

This small, qualitative descriptive, pilot study was conducted in Kisumu, Kenya. ${ }^{18}$ The location was selected because the Canadian researchers had existing collaborations with researchers in Kenya, and because Kenya is a low-income country where migration is common. The setting was therefore deemed ideal for determining the feasibility of conducting transnational research on the phenomenon of transnational family support and for gathering pilot data.

DM and DO, locally based in Kenya, recruited (via posters and word of mouth) a convenience, purposive sample of nine adults ( 6 men and 3 women), who self-identified as providing support to family members who migrated to another country. 'Support' was left open to the interpretation of the participants, but was broadly defined as emotional, instrumental, financial and/or material help, as well as providing advice and/or information. The study was explained at the time of recruitment and consent forms were signed in Kisumu. The study was briefly re-explained and consent reconfirmed verbally by phone at the time of the interview. We gathered data through semi-structured interviews using Skype to call participants (on their cell phones) in Kenya; LM conducted the interviews from Canada between May and July 2018. This approach was selected as it did not require the participants to have access to internet, it allowed for flexibility in scheduling the interviews, since all participants had cell phones, and because it ensured no costs were incurred by participants. Using Skype also facilitated the recording (Skype has an application for this), and was relatively inexpensive.

Interviews were in English, lasted between 20 and 45 minutes, and were audio-recorded. We asked participants to first describe their context (who migrated and when, and the circumstances of migration). We then asked them to discuss their relationship to their family member(s) who migrated; the nature and kind of support they gave and how they maintained contact with their family; and their thoughts and feelings, both positive and negative, about their experience of providing support. Following these questions, we asked participants to share their opinions regarding the relevance, feasibility and how best to conduct this type of research (eg, who we should speak with, what questions to ask, feasibility aspects and potential barriers to participation). We collected some basic socio-demographic information from each participant and kept field-notes, including general details and impressions about the interview process (i.e., what worked and yielded more data and what was more challenging).

Interviews were transcribed verbatim. Transcripts and field-notes were compiled and analysed over the data collection process. To address the feasibility questions, LM re- 
viewed and extracted relevant information from the fieldnotes and the direct feedback received from participants during the interviews regarding conducting research on transnational family support from family members back home. This information was then used to generate a summary of the key points to consider when conducting this type of research.

To begin to identify themes related to the experiences of providing transnational support to migrant families living in another country we also performed a content analysis of the interview data. ${ }^{19}$ This process was led by the first author (LM), and supported by NE. LM read and reviewed all transcripts multiple times to identify patterns in the data; NE read a selection of three interviews. We then abstracted sections of the transcripts and grouped them into categories based on the patterns that we had identified. Both LM and $\mathrm{NE}$ reviewed the categories and regrouped them into larger themes; this was an iterative process and was done until agreement was reached. We then refined the labels and selected quotes that best supported and illustrated the categories and themes. DO and DM were not involved in the analysis of the raw data given they were acquainted with some of the participants. They did however, review and confirm their agreement with the final themes. Participants' socio-demographic and contextual information were summarized.

We received ethical approval from the University of Ottawa and from the Great Lakes University of Kisumu. Approval was also obtained from the National Commission for Science, Technology and Innovation (NACOSTI) and from the advisory institutions of the Government of Kenya on matters of research.

\section{RESULTS}

The participants' characteristics are reported in Table 1; they described a range of migration situations and relationships to the family members who were living abroad. Seven participants spoke about only one family member who had migrated, while three participants spoke about more than one family member (i.e., three brothers, three cousins, and their wife and children respectively). Most of the migrant family members were living in the US; for some the move was recent, while for others it was many years ago; one family member was born in the US (her parents had migrated). The reason for migration was mainly to study; almost all of the participants' family members planned to stay abroad permanently. Two of the participants had been migrants themselves (to the US) but had since returned to Kenya.

\section{FEASIBILITY OF CONDUCTING TRANSNATIONAL RESEARCH}

Participants were generally positive about the study and thought that the research was relevant. One participant stated: "Whatever comes out of this study should be utilized, not kept in a shelf somewhere... to assist families." While another requested to have the results: "I just want to know how we get the research findings of the study you are conducting. I may be interested to get the findings." Overall participants were open and willing to share their experiences and most
Table 1. Description of participants

\begin{tabular}{|c|c|}
\hline Descriptor & Number of participants $(n=9)$ \\
\hline \multicolumn{2}{|l|}{ Sex: } \\
\hline Male & 6 \\
\hline Female & 3 \\
\hline \multicolumn{2}{|l|}{ Age (in years): } \\
\hline $20-30$ & 1 \\
\hline $31-50$ & 4 \\
\hline$>50$ & 4 \\
\hline \multicolumn{2}{|l|}{ Education level: } \\
\hline University degree & 9 \\
\hline \multicolumn{2}{|c|}{ Relationship to family member(s) living in another country: } \\
\hline Sibling & 4 \\
\hline Parent & 1 \\
\hline Cousin & 2 \\
\hline Uncle & 1 \\
\hline Husband and father & 1 \\
\hline \multicolumn{2}{|c|}{ Country where family member(s) are living: } \\
\hline US & 7 \\
\hline UK & 1 \\
\hline Canada & 1 \\
\hline \multicolumn{2}{|c|}{ Number of years family member(s) has/have been away: } \\
\hline$<3$ & $3^{*}$ \\
\hline 3-10 & 1 \\
\hline$>10$ & 6 \\
\hline \multicolumn{2}{|c|}{ Primary purpose for migration: } \\
\hline Education & 8 \\
\hline Employment & $3 \dagger$ \\
\hline
\end{tabular}

"One of the participants who spoke about more than one family member had family members who moved less than three years ago and also within the last ten years. †Two of the participants who spoke about more than one family member had family members who moved for education and employment.

felt that others like them would also be interested and receptive to participating in such research. Table 2 presents the factors that participants believed might influence participation and data collection. They highlighted the importance to speak with different family members and to ask a range of questions during the interviews in order to obtain diverse perspectives and more detailed accounts of experiences especially on more negative aspects. They warned that family dynamics will also affect what is shared by each family member. They also expressed that privacy concerns and emotions could affect one's willingness to participate and/or what information a participant would feel comfortable disclosing.

Interviewing participants by phone from Canada proved feasible, however there were some challenges. These included communication issues due to language barriers (English was their second language and it was difficult to understand their accents) and background noise; coordinating a time to speak, especially given geographic time differences; and technical difficulties (cell phone battery dying, phone not being turned on when the interviewer called). Not speaking face to face (and without the video 
Table 2. Potential factors affecting the participation and data collection from family "back home" in transnational research

\begin{tabular}{|c|c|}
\hline Factor & Supporting Quotes \\
\hline \multicolumn{2}{|l|}{ Participation } \\
\hline \multirow{3}{*}{$\begin{array}{l}\text { The timing of interviews and } \\
\text { cost and time commitment } \\
\text { required for participation }\end{array}$} & $\begin{array}{l}\text { "Yeah, as long as people... It's not going to cost them. People will talk to you. As long as it doesn't } \\
\text { cost them. They will open up." }\end{array}$ \\
\hline & "Yeah people may be interesting [in participating] based on the availability." \\
\hline & "Depending on the time consumption, he'll be able to give you his or her time." \\
\hline \multirow{3}{*}{$\begin{array}{l}\text { The family's interest in } \\
\text { research and eagerness to } \\
\text { help }\end{array}$} & "It would depend on their interest [whether people would agree to participate]." \\
\hline & $\begin{array}{l}\text { "I thought it [participating in a study] would be a good forum for me to express myself and be a } \\
\text { part of the interview." }\end{array}$ \\
\hline & "I thought I would be happy to be part of someone's success [reason for participating]." \\
\hline \multirow[t]{2}{*}{$\begin{array}{l}\text { The belief that they may have } \\
\text { some gain, monetary or } \\
\text { otherwise, in participating }\end{array}$} & $\begin{array}{l}\text { "There is a number of people who wants to be involved in such kind of studies because most of } \\
\text { the Kenyans are interested in going abroad so anything to do with abroad they will be very much } \\
\text { interested..." }\end{array}$ \\
\hline & $\begin{array}{l}\text { "There are also some people who are monetary motivated in that they have some kind of cash at } \\
\text { the end and then they are willing to give you their time." }\end{array}$ \\
\hline \multirow[t]{2}{*}{$\begin{array}{l}\text { Mistrust or fear of } \\
\text { repercussions if they } \\
\text { participate }\end{array}$} & $\begin{array}{l}\text { "Maybe others might think it is something malicious or someone is going to follow them up so } \\
\text { then somebody might not agree [to participate]... or if they think it's something that is not } \\
\text { genuine." }\end{array}$ \\
\hline & $\begin{array}{l}\text { "Maybe they [families back home] have in mind that there will be some kind of follow up activities } \\
\text { that may affect their families or something as such..." }\end{array}$ \\
\hline \multicolumn{2}{|l|}{ Data collection } \\
\hline \multirow[t]{2}{*}{$\begin{array}{l}\text { Which family members are } \\
\text { interviewed }\end{array}$} & $\begin{array}{l}\text { "Like I think if you talk to my brother in law, he may not say bad things about my daughter } \\
\text { because that's the brother's kid, but I'm sure if you talked to my sister in law, she would give you } \\
\text { different thoughts because she even got angry with me." }\end{array}$ \\
\hline & $\begin{array}{l}\text { "Sometimes it's good to get different members of the family, just to have a view of what they } \\
\text { think. Look for people so you can have several parents, brothers...mothers in law [to participate], } \\
\text { so a variety of people..." }\end{array}$ \\
\hline \multirow{2}{*}{$\begin{array}{l}\text { How questions are asked and } \\
\text { family dynamics }\end{array}$} & "So it depends on how you ask the question... then you will get some negative..." \\
\hline & $\begin{array}{l}\text { "People feel good and say good things if they are benefitting from that person, but if they're not } \\
\text { benefitting then I'm not sure, what exactly what kind of things they will say..." }\end{array}$ \\
\hline \multicolumn{2}{|l|}{ Participation and data collection } \\
\hline $\begin{array}{l}\text { The emotions (sadness, } \\
\text { distress) that interview } \\
\text { questions may evoke }\end{array}$ & $\begin{array}{l}\text { "I don't think the families would refuse. But there is an element of emotion that could come in } \\
\text { particularly if you get a family who has lost their son or their relatives for a very long time and } \\
\text { they are somehow disturbed about it." }\end{array}$ \\
\hline Privacy concerns & $\begin{array}{l}\text { "...somebody doesn't want to comment about his family affairs. Family affairs remains family } \\
\text { affairs. He doesn't want to divulge it to other parties that are not family members." }\end{array}$ \\
\hline
\end{tabular}

function of Skype) was less personal and also meant that non-verbal expressions could not be captured. For those participants who had access to internet, they said that they would have been open to a WhatsApp video call (participants were less familiar with Skype), although they admitted that the quality of the internet connection may have prohibited this approach. When asked about the possibility of conducting group interviews with their migrant family members, all participants said that they would be comfortable with this as long as their family members were in agreement.

\section{PILOT RESULTS: EXPERIENCES OF PROVIDING TRANSNATIONAL FAMILY SUPPORT}

We identified four main themes related to the experience of providing transnational family support: 1) Nature, means and type of support; 2) Shifts in support over time and influences on nature and type of support; 3) Expectations of those back home and bi-directional support; and 4) Strain, stresses and tensions (Table 3). Results showed that multiple family members tend to be involved in giving support to family who migrate. The support may take different forms, may be local, and often shifts over time, with assistance being more intense during the early resettlement period and in times of financial difficulty. In some instances, support (e.g., childrearing advice) may be less welcomed or challenging to give. It also appears that the context and age at migration affect the amount of support needed while the relationship and degree of closeness, gender, age and life circumstances shape the nature and intensity of support given by individual family members. The amount of contact and how communication is maintained (e.g., Facebook, WhatsApp, phone) and with whom, also varies. Important factors affecting communication include access to technology, logistics, closeness to the migrant family member(s) and financial means. 
Table 3. Pilot results on transnational family support: perspectives and experiences from "family members back home"

\begin{tabular}{|c|c|}
\hline Theme & Supporting Quotes \\
\hline \multicolumn{2}{|l|}{ Nature, means and type of support: } \\
\hline \multirow{9}{*}{$\begin{array}{l}\text { Different forms of support may be provided } \\
\text { (financial, emotional spiritual, practical) }\end{array}$} & $\begin{array}{l}\text { "We provided some little money for his upkeep during the time he arrived there. He } \\
\text { could tell us he was missing some little money because he was not yet familiar with } \\
\text { that place." }\end{array}$ \\
\hline & $\begin{array}{l}\text { "We would get [send] money for upkeep and also for her staying there before she } \\
\text { could stabilize there." }\end{array}$ \\
\hline & "Yeah... emotionally... I think that's the main support we give to her." \\
\hline & "...but the main thing you can do is talk to them and encourage them..." \\
\hline & "My American family they need me socially but economically they are ok." \\
\hline & "I stay online with her for hours... pray with her..." \\
\hline & "I helped her find a job because I'm familiar with the American system." \\
\hline & $\begin{array}{l}\text { "I requested one of my friends if they can help her stay at their house for about a } \\
\text { month until we get her an apartment..." }\end{array}$ \\
\hline & "Yeah, he [sister's son] is living with us, the family that remained here..." \\
\hline \multirow{3}{*}{ Support may be back home } & $\begin{array}{l}\text { "This one child is learning in a certain local school [in Kenya] which is not very } \\
\text { expensive so that at least she [the mother who remained in Kenya] and the other } \\
\text { family members can sustain the boy in school." }\end{array}$ \\
\hline & $\begin{array}{l}\text { "...if they want to inspect some houses at home ... we buy land for them...They are } \\
\text { not here- they send money and then we go and we buy for them ... that is the way } \\
\text { we are helping them". }\end{array}$ \\
\hline & $\begin{array}{l}\text { "So there used to be this moment when the mom [my aunt] was sick I would always } \\
\text { go and take good care of her in the hospital, see her, visit her and give feedback on } \\
\text { how her mom is getting on. Basically that is the kind of support, but not financial..." }\end{array}$ \\
\hline \multirow{6}{*}{$\begin{array}{l}\text { Families maintain contact to varying } \\
\text { degrees and use different means to } \\
\text { maintain contact and communication; also } \\
\text { depends on access to technology, financial } \\
\text { means and logistics }\end{array}$} & $\begin{array}{l}\text { "My uncle has an email address which they use to communicate because he has an } \\
\text { email address and Wi-Fi in the office. In case I have to use the internet I have to ask } \\
\text { him and then I can give me the internet and then I communicate with other people." }\end{array}$ \\
\hline & $\begin{array}{l}\text { "We are using WhatsApp. But mostly it is usually them who ring, not us. Their } \\
\text { schedule is a bit different than with ours. With ours they can call anytime but with } \\
\text { them it has to be a specific time." }\end{array}$ \\
\hline & "...she's on WhatsApp with family members... with her cousins she's on Facebook..." \\
\hline & "By phone, we use the phone." \\
\hline & "...calling her every other day, sending her text messages... I write letters." \\
\hline & $\begin{array}{l}\text { "But there are challenges. Basically economic. Because unless you have good, high } \\
\text { income travelling is very expensive. So that is something. Most of the immigrant } \\
\text { people they are not able to visit as often as they wish. That is a challenge." }\end{array}$ \\
\hline
\end{tabular}

Shifts in support over time and influences on nature and type of support:

"At one point we had to organize for a fund raising in order to send him some money so that he could make some ends to meet. So at one point we did some fundraising to send him some money for the upkeep and part of it to pay for his units [courses] that he was finalizing with."

Support may vary with time and circumstances

"Financially we can help him when he's stuck."

"Yeah, for the first year we were assisting him. But after some couple of years he was assisting himself."

"I believe that support may be in the initial stages, then after the family in the US stabilizes then the support doesn't come as much. Then the person in the US supports those back home, financially."

"Yeah, she was young, but it was not so difficult when she moved. Because already she could have some people out there to interact with."

Reason, context and age at migration may influence need for support

Relationship and/or closeness to migrant, age and gender may influence nature and
"They had adequate resources. My wife was employed. I had left to them a house. So basically they were well taken care of... they need me socially but economically they are ok."

"The one [brother] who went 10 years back made the way for the other two."

"Personally I don't have a contact. It's an uncle of mine that is very close to him that has his contact." 


\begin{tabular}{|c|c|}
\hline Theme & Supporting Quotes \\
\hline & "I guess because I'm her mother the support just comes naturally." \\
\hline & $\begin{array}{l}\text { "... the boy literally got brought up in our home... So he grew like my child. He was } \\
\text { my nephew so of course I support him." }\end{array}$ \\
\hline
\end{tabular}

intensity of support

Childrearing support may be less welcomed or more challenging due to language barriers and/or families' may be less interested or inclined to give or are not as close with children abroad

"With her cousins. She's on Facebook..."
"I also have bigger children, he is more closer to my children, they communicate
quite a number of times, not so much with me. Their aunt, that's my wife, is also a bit
more closer to him."
more closer to him."

"Because when you have children in the first world like the US, the kids have that culture. We don't take advice, we feel that in the US we have better advice, better knowledge, it looked like things were not as good here, as far as raising a child is concerned."

"I think I was adequately well informed on how to take care of my children [in the US]. Actually my mother [in Kenya] she did not have the capacity to do that."

\begin{tabular}{l}
\hline "Yes, we just saw them [the children]. But we don't contact them." \\
\hline "Yes I will keep contact [with grandchildren in the US], but I am not really \\
sentimental about those issues..." \\
\hline "... But they [my family in Kenya] had difficulty communicating with my children \\
because my children did not learn my local language."
\end{tabular}

\section{Expectations from those back home and bi-directional support:}

"In fact they are helping us a great deal. I am very happy for them. They are doing well. And the upkeep of my parents they are taking care of them. They are also sponsoring our other brother there."

"Domestic things...they send money. Medical expenses. If we have a funeral... they come in and they assist."

Support is often bi- directional

"And also sometimes he was assisting us. For most of the time he was assisting us."

"Yeah he sends money. And also moral support. Like prayer."

"I had a good friend who brought her aunt who stayed with her about five years [in the US]. Until the kid was five. But in exchange they bought her a piece of land. Because she was a widow."

"We are expecting that if things go well he can even support some of my siblings. Also for their education."

"They support themselves. Also I support myself in Kenya. I am employed in Kenya... No I don't need their support."

Expectations from migrant families vary

"I can say that I can make my own way by myself. And what I want. I don't need to ask them for support or for money. So I can't say that I got any support from them."

"If they're aware of the structure their family is living in, like maybe their mother or dad, maybe living in poor conditions then I also think they have an obligation of using their opportunity to stay in the united states to be able to build a good house for their family member."

\section{Strain, stresses and tensions:}

Transnational context generally may cause family tensions, sadness or difficult situations

Support giving may cause strain and/or family tension
"Yes it was [difficult at first]... He [my nephew] just got used to his mom being away... so I think things are just ok now."

"Looking at all these things he is not better off in Canada... Yeah very difficult for the wife...For the wife and for us all."

"The parents may feel really disappointed, because their child went to the US expecting them to complete school, get a job, and then support the family. In Africa that is very normal. And then the child disappears, so that is very sad."

"Some are bitter and [think] why should they be in the US and not me."

"...he wanted to support his sister [in Kenya] who was in secondary school, and he started sending money to help his sister. But then the money was coming through the elder brother who was now not channeling that money, not using that money to the school. It actually was a bit of a problem... I think that kind of brought bad relationship."

"But we really sympathize with his wife plus his young boy the son [who stayed behind]...So at certain times we have to chip in economically here and there and we also have our families to take care of."

"...the difficulty was during the time we were supporting him, we also happened to 


\begin{tabular}{ll}
\hline Theme & Supporting Quotes \\
\hline & $\begin{array}{l}\text { have another of fellow children in school and at that time the finances were a bit } \\
\text { low on our side, so actually it was not so easy to actually support him to his } \\
\text { satisfaction." }\end{array}$ \\
\cline { 2 - 2 } & "My father in law was very supportive. And he insisted that the family had to chip in \\
& $\begin{array}{l}\text { to pay for my daughter... It created animosity. I'm not in good terms with my brother } \\
\text { in law because of that because they said I should have convinced her to stay here..." }\end{array}$ \\
\hline
\end{tabular}

Overall the families were generally positive about their family members' migration, however, the transnational family context did present some challenges. Family members missed and worried about each other, many back home had expectations of return support, which was not always fulfilled, and there were situations that caused family strife. For some, the support-giving to migrant family members also caused financial strain, family conflict and tension among those back home.

\section{DISCUSSION}

The key findings from this study are that families back home are interested and willing to participate in a study on transnational family support and that it is feasible to conduct interviews and to collect data from family members back home using communication technology. The pilot data gathered also shows that obtaining the perspectives from family back home who are providing the support to their migrant family members yields informative data on the phenomenon of transnational family support.

\section{IMPLICATIONS FOR CONDUCTING TRANSNATIONAL RESEARCH WITH FAMILY BACK HOME}

To gather a diversity of perspectives and experiences, a range of family members within and across families (various relationships and closeness, gender, age, circumstances) in different migration contexts, including both recent and non-recent migration, should be recruited. To elicit data on both positive and negative experiences, a variety of questions that explicitly ask about different kinds of support provided, challenges, less welcomed support, negative impacts and tensions, as well as expectations, benefits, and emotions, must be asked. There appears to be an openness to conducting family group interviews, although to collect information on more sensitive topics family members should be interviewed individually since they may be reluctant to share personal feelings with other family members present. Family dynamics should also be considered during the interviews and when interpreting the findings.

Flexibility is essential when coordinating interviews, including accommodating different schedules and time zones and adapting to unforeseen situations (e.g., background noise, phone dying) that may arise during interviews. While this is relevant to any cross-country study, the constraints are likely greater for those in a low-income country. For example, access to electricity to charge a phone or finding a quiet, private location to hold a discussion may be more of an issue. Another consideration with regards to the timing the interviews, is also access to technology. We decided to conduct the interviews by phone calls since we knew that participants all had cell phones and this would broaden the scheduling options. Had we decided to use the internet, for those with no home access, we would have had to coordinate interviews based on when they could go to the University (organized by our colleagues locally). This would have incurred additional costs, been more burdensome for the participants, and likely would have reduced participation. In our planned Canadian study where participants back home will be in multiple countries, coordinating a location where participants can go to access internet will not really be a reasonable option, as it will be too unwieldly to organize across so many sites.

Data collection approaches should also be flexible. We used Skype to call participants and this worked well, although we could not gather observational data. The range of ways that families maintain contact (Facebook, WhatsApp, phone, Skype), however, could offer various options (phone, video, texts, emails) for communicating with families and also different types of data (interviews, pictures, written exchanges, observations). ${ }^{20-22}$ Given that access and knowledge on how to use technology/internet varies, as well as capacity and comfort levels in disclosing personal information, using a mix of sources and approaches for gathering data may be the most beneficial. As with any cross-linguistic study, having interviewers who speak the maternal language of those back home would also improve communication by addressing language barriers, especially when there is no face-to-face (video) interaction and there is background noise, making it more difficult to understand what participants are saying. ${ }^{23,24}$

Given some of the issues (mistrust, communication barriers, privacy concerns, negative emotions) that may affect what participants share, it may be best to have more than one contact with participants. Multiple interviews may allow families to open up over time and feel more comfortable disclosing as they get to know the interviewer. ${ }^{23,24}$ Followup interviews would also provide an opportunity to ask for clarifications and to validate interpretations. Additional contacts may also allow the researchers to tap in to other data sources (e.g., pictures, text exchanges between family members) that participants discuss in their first interview.

The results also reveal certain ethical issues to consider when conducting transnational distance interviews. Firstly, the importance of ensuring that consent is informed and voluntary and that family members are clear on what participation involves, especially if consent is only obtained over the phone/internet and there are language barriers. In the current study participants were recruited by researchers locally, however in our future work we intend to recruit participants back home via the migrant families in Canada. In such research, it will therefore be imperative to have ad- 
ditional time to explain the study and to respond to questions, and to implement strategies in order to confirm that family members understand what is being asked of them, as well as the potential benefits and harms, if they choose to participate. This would include using known strategies such as, repetition, the use of simple language, allowing them to read the consent form in advance, asking them to explain back what they understand, and ensuring information is presented in their language. ${ }^{23-27}$ Given the vulnerability of certain families, i.e., some family members back home hoping to migrate, and some migrant family members still being in the process of filing their immigration application, or being in a precarious immigration situation, it must also be made explicit to participants that their participation or non-participation will have no impact on them or their migrant family members, and that the researchers have no role in immigration processes. ${ }^{23-27}$ The economic situation of families should also be considered; to avoid any potential conflicts or discomfort there should be complete transparency regarding any monetary compensation that may be given to either the migrants or the participants in the home country.

The second ethical issue is regarding how researchers may adequately respond from a distance, to families who may become emotional or distressed during interviews. The participants in this study expressed some sadness and also discussed tensions and conflicts related to their family members' migration, and also due to expectations of return assistance not being met. Interviewers therefore need to be sensitive to these potential issues and be cautious to not cause or aggravate family stress. It is therefore critical to emphasize to participants that they have the right to not respond to questions that they prefer not to answer, and that they may withdraw their participation and data at any time; this is especially so if participants are unfamiliar with research, and their rights as participants. Additional time (or contacts) could also be allocated to ensure interviewers or a specialist on the team can provide psychological support (by phone or internet) as needed. ${ }^{23,24}$ If feasible, local supports should be identified for referrals as well. Research is also warranted to further develop guidelines for ethical issues that may arise when conducting research using communication technology in a transnational context, especially when multiple countries are involved and/or families back home may be living in unstable or war torn areas. ${ }^{28,29}$

\section{TRANSNATIONAL FAMILY SUPPORT AND IMPLICATIONS FOR POPULATION HEALTH}

The pilot results, although preliminary, add to the body of literature on transnational family support for migrants. They showed that different kinds of support are provided, including financial, emotional, practical and spiritual, as well as various types of support back home, and that a range of factors influence its nature and intensity. They also showed that some support may be less welcomed by migrants, or families may find it challenging to give, or feel less inclined to provide it. Consistent with other research, we found that families are mostly positive about their family member's migration but that there are also some neg- ative effects, including strain, tensions, and family conflict that are directly related to the support-giving. ${ }^{3,9,10}$ Our results also showed that support is often bi-directional, although expectations of those back home can vary. Overall the findings highlighted that experiences are complex and diverse.

There is an emerging body of literature regarding transnational ties (social, economic, cultural) to the home country and the health and well-being of migrants, which indicates both beneficial and adverse effects on life-style behaviours, psycho-social health and disease management. ${ }^{10,30-34}$ The preliminary findings here suggest that financial and practical support from family back home help migrants with settling into the new country, while emotional and spiritual support may provide a sense of connectedness and motivation in the face of loneliness and discouragement due to resettlement challenges. Family assistance provided back home also helps with maintaining family and other commitments and may foster a close connection with home. It also helps migrants continue to sustain their lives in the home country (e.g., homes) for when they plan to return. Transnational family support therefore seems to be an important resource, in providing not only a psycho-social function, but also in providing tangible practical and economic assistance to migrants, that extends across borders.

Future work is needed to explore transnational family support (towards migrants) more in depth and to better understand the impacts, both positive and negative on health, for migrants as well as on their family members back home. For migrants, despite the distance, family back home are evidently having a role in shaping both the social and physical environments of migrants in the new country and they are likely also shaping day-to-day decisions and behaviours. Similarly, providing transnational support is having an impact on the living conditions (e.g., by reducing financial resources) and social environments (eg, affecting relationships between family members) of family in the home country. Receiving and providing transnational family support therefore has implications for both health risk and protection for migrants and their families in the sending countries.

Transnational family support also has implications for health and social care, programming and policies for migrants in receiving-countries. For example, policies that affect transnational transportation, communication, importation of goods, and banking and migration (e.g., travel visas) can facilitate or create barriers to the provision of transnational family support. ${ }^{35}$ Migrant employment policies and integration programs, can also reduce or increase the need for financial support from family back home. Support programs and care-providers working directly with migrants could also play a role in supporting and assisting migrants to mobilize transnational family support as a resource and/or in mitigating the negative effects for both migrants and for the family who are providing support from a distance. For the latter, studies will be needed to determine how this may be best achieved. 


\section{LIMITATIONS}

This was a pilot study meant to inform the methods for a larger study. The sample was small, highly educated, English speaking and represented the views of a select sample in Kenya whose family members had all moved for the purpose of education or employment. In other low-or middleincome countries, or migration contexts, there may be different feasibility issues that were not captured here. Different populations may also have different views and interest in participating in this type of research. The results presented here regarding the experience of providing transnational family support are also very preliminary since collecting pilot data was a secondary goal.

\section{NEXT STEPS}

The planned Canadian study will build from this pilot work. We plan to focus on migrant families with children and will aim to better understand transnational family support specifically in relation to parenthood in a new country and the related health outcomes. We will recruit a diverse migrant population (various countries of origin and migration trajectories) as well as their family members back home, including different relationships. Based on the pilot experience, data collection will consist of a mix of group (migrants and their family back home together) and individual (migrants and family members back home separately) interviews, with more than one contact, and we will attempt to tap into other data sources as well (pictures, text exchanges). Questions will explore both positive and negative experiences from the perspectives of the migrant families as well as those providing support from a distance, including how they believe this may impact their health. To optimize participation we will use a mix of phone and internet, and will offer different modes for communication (WhatsApp, Skype). Interview times will be flexible, and we will be sure to allocate sufficient time for explaining the study and obtaining consent. The research team will be available to respond to any participants, local or abroad, in the case where they experience distress.

\section{CONCLUSIONS}

This pilot study shows that family members back home are willing to engage in research on transnational family support. It also shows that using communication technology is efficient and logistically feasible for interviewing and collecting data from migrants' family members who remain in the home country. It also demonstrates that informative data on transnational family support can be generated by including family members' back home in research.

\section{ACKNOWLEDGEMENTS}

The authors acknowledge the Great Lakes University of Kisumu for their logistical support and the School of Public Health at Mount Kenya University for facilitating the dissemination of the findings at their first Public Health Conference held on 23rd - 25th October, 2018 in Thika, Kenya.

\section{FUNDING}

LM was supported by a Post-doctoral award for healthcare professionals, by the Fonds de Recherche Québec- Santé (FRQ-S). The research activities were supported by NE's general research funds at the University of Ottawa and LM's start-up research funds at the University of Montreal.

\section{COMPETING INTERESTS}

The authors completed the Unified Competing Interest form at http://www.icmje.org/coi_disclosure.pdf (available upon request from the corresponding author), and declare no conflicts of interest.

\section{CORRESPONDENCE TO:}

\section{Lisa Merry, RN, $\mathrm{PhD}$}

Faculty of Nursing, University of Montreal

Pavillon Marguerite-d'Youville, Room 6061

2375 Côte-Ste-Catherine road

Montreal, QC H3T 1A8

Canada

lisa.merry@umontreal.ca 


\section{REFERENCES}

1. Levitt P, Jaworsky BN. Transnational migration studies: Past developments and future trends. Annu Rev Sociol. 2007;33:129-156. doi:10.1146/annurev.so c.33.040406.131816

2. Zontini E, Reynolds T. Ethnicity, families and social capital: caring relationships across Italian and Caribbean transnational families. Rev Int Sociol. 2007;17(2):257-277. doi:10.1080/03906700701357042

3. Baldassar L. Transnational families and the provision of moral and emotional support: The relationship between truth and distance. Identities. 2007;14(4):385-409. doi:10.1080/10702890701578423

4. Merla L. Salvadoran Migrants in Australia: An Analysis of Transnational Families' Capability to Care across Borders. Int Migr. 2015;53(6):153-165. doi:10.1 111/imig.12024

5. Ukwatta S. Sri Lankan female domestic workers overseas: mothering their children from a distance. $J$ Popul Res. 2010;27(2):107-131. doi:10.1007/s12546-0 10-9035-0

6. Glick JE. Connecting complex processes: A decade of research on immigrant families. J Marriage Fam. 2010;72(3):498-515. doi:10.1111/j.1741-3737.2010.00 $\underline{715 . \mathrm{X}}$

7. Marchetti-Mercer MC. Those easily forgotten: the impact of emigration on those left behind. Fam Process. 2012;51(3):376-390. doi:10.1111/j.1545-530 $\underline{0.2012 .01407 . \mathrm{x}}$

8. Marchetti-Mercer MC. "If You Uproot a Tree You Leave a Big Hole Behind": Systemic Interconnectedness in Emigration and Family Life. Contemp Fam Ther. 2016;38(3):339-352. doi:10.1007/s 10591-016-9386-6

9. Poeze M, Dankyi EK, Mazzucato V. Navigating transnational childcare relationships: migrant parents and their children's caregivers in the origin country. Glob Netw. 2017;17:111-129. doi:10.1111/glo $\underline{\text { b. } 12135}$

10. Viruell-Fuentes EA, Schulz AJ. Toward a dynamic conceptualization of social ties and context: implications for understanding immigrant and Latino health. Am J Public Health. 2009;99(12):2167-2175. do i:10.2105/ajph.2008.158956

11. Ryan L, Sales R, Tilki M, Siara B. Social networks, social support and social capital: The experiences of recent Polish migrants in London. Sociology. 2008;42(4):672-690. doi:10.1177/0038038508091622
12. Levitt P, Schiller NG. Conceptualizing simultaneity: A transnational social field perspective on society. Int Migr Rev. 2004;38(3):1002-1039. doi:1 0.1111/j.1747-7379.2004.tb00227.x

13. International Organization for Migration (IOM). International Dialogue on Migration 2014. Human Mobility and Development: Emerging Trends and New Opportunities for Partnerships, Intersessional Workshop on Migration and Families. Summary of Discussions. IOM; 2014.

14. Dreby J. Parent-Child Separation in Mexican Transnational Families. Dissertation. City University of New York; 2008.

15. Schmalzbauer L. Searching for wages and mothering from afar: The case of Honduran transnational families. J Marriage Fam. 2004;66(5):1317-1331. doi:10.1111/j.0022-2445.200 4.00095.X

16. Baldassar L. Transnational families and aged care: the mobility of care and the migrancy of ageing. $J$ Ethn Migr Stud. 2007;33(2):275-297. doi:10.1080/1369 1830601154252

17. Marcelletti Rocha de Oliveira G. Transnational Care Constellations: Mexican Immigrant Mothers and Their Children in Mexico and in New York City. Dissertation. Columbia University; 2015.

18. Neergaard MA, Olesen F, Andersen RS, Sondergaard J. Qualitative description - the poor cousin of health research? BMC Med Res Methodol. 2009;9:52. doi:10.1186/1471-2288-9-52

19. Elo S, Kyngäs H. The qualitative content analysis process. J Adv Nurs. 2008;62:107-115. doi:10.1111/j.1 365-2648.2007.04569.x

20. Wilding R. "Virtual” intimacies? Families communicating across transnational contexts. Glob Netw. 2006;6(2):125-142. doi:10.1111/j.1471-0374.20 06.00137.x

21. Janghorban R, Roudsari RL, Taghipour A. Skype interviewing: The new generation of online synchronous interview in qualitative research. Int $J$ Qual Stud Health Well-being. 2014;9:24152. doi:10.340 2/qhw.v9.24152

22. Sullivan JR. Skype: An appropriate method of data collection for qualitative interviews? The Hilltop Review. 2012;6:10. 
23. Merry L, Clausen C, Gagnon AJ, et al. Improving qualitative interviews with newly arrived migrant women. Qual Health Res. 2011;21(7):976-986. doi:1 $\underline{0.1177 / 1049732311403497}$

24. Merry L, Low A, Carnevale F, Gagnon AJ. Participation of childbearing international migrant women in research: The ethical balance. Nurs Ethics. 2016;23:61-78. doi:10.1177/0969733014557134

25. Ogilvie LD, Burgess-Pinto E, Caufield C. Challenges and approaches to newcomer health research. J Transcult Nurs. 2008;19:64-73. doi:10.117 $\underline{7 / 1043659607309142}$

26. Yancey AK, Ortega AN, Kumanyika SK. Effective recruitment and retention of minority research participants. Annu Rev Public Health. 2006;27:1-28. do i:10.1146/annurev.publhealth.27.021405.102113

27. Frayne SM, Burns RB, Hardt EJ, Rosen AK, Moskowitz MA. The exclusion of non-Englishspeaking persons from research. J Gen Intern Med. 1996;11:39-43. doi:10.1007/bf02603484

28. Mazzucato V, Schans D. Transnational families and the well-being of children: Conceptual and methodological challenges. J Marriage Fam. 2011;73(4):704-712. doi:10.1111/j.1741-3737.2011.00 $\underline{840 . \mathrm{x}}$

29. Barglowski K, Bilecen B, Amelina A. Approaching transnational social protection: Methodological challenges and empirical applications. Popul Space Place. 2015;21(3):215-226. doi:10.1002/psp.1935
30. Afulani PA, Torres JM, Sudhinaraset M, Asunka J. Transnational ties and the health of sub-Saharan African migrants: The moderating role of gender and family separation. Soc Sci Med. 2016;168:63-71. doi:1 0.1016/j.socscimed.2016.09.009

31. Pannetier J, Lert F, Roustide MJ, du Loû AD. Mental health of sub-Saharan African migrants: The gendered role of migration paths and transnational ties. SSM Popul Health. 2017;3:549-557. doi:10.1016/ j.ssmph.2017.06.003

32. Alcántara C, Molina KM, Kawachi I.

Transnational, social, and neighborhood ties and smoking among Latino immigrants: Does gender matter? Am J Public Health. 2015;105(4):741-749. do i:10.2105/ajph.2014.301964

33. Faist T, Bilecen B, Barglowski K, Sienkiewicz JJ. Transnational social protection: migrants' strategies and patterns of inequalities. Popul Space Place. 2015;21(3):193-202. doi:10.1002/psp.1903

34. Sanon MA, Spigner C, McCullagh MC. Transnationalism and hypertension self-management among Haitian immigrants. J Transcult Nurs. 2016;27(2):147-156. doi:10.1177/1043659614543476

35. Merla L. The transnational family. Accessed February 21, 2019. https://cdn.uclouvain.be/public/Ex ports\%20reddot/iacchos/images/pub(1).pdf 